\title{
Decreasing the ratio of matriptase/HAI-1 by downregulation of matriptase as a potential adjuvant therapy in ovarian cancer
}

\author{
PENGMING SUN $^{1}$, ZHONGQING JIANG $^{2}$, XIAOFANG CHEN $^{2}$, LIFANG XUE ${ }^{1}$, \\ XIAODAN MAO ${ }^{1}$, GUANYU RUAN ${ }^{1}$, YIYI SONG ${ }^{1}$ and ALEXANDER MUSTEA ${ }^{3}$ \\ ${ }^{1}$ Institute of Gynecologic Oncology, Department of Gynecology, Fujian Maternity and Children Health Hospital, \\ Teaching Hospital of Fujian Medical University, Fuzhou, Fujian 350001; ${ }^{2}$ Department of Obstetrics and Gynecology, \\ The First Affiliated Hospital of Fujian Medical University, Fuzhou, Fujian 350005, P.R. China; \\ ${ }^{3}$ Gynecological Tumor Center, Department of Obstetrics and Gynecology, \\ Medical University Greifswald, D-17475 Greifswald, Germany
}

Received July 3, 2015; Accepted May 5, 2016

DOI: $10.3892 / \mathrm{mmr} .2016 .5435$

\begin{abstract}
Tumor invasion and metastasis are complex biological processes. Matriptase and its endogenous inhibitor, hepatocyte growth factor activator inhibitor-1 (HAI-1) are involved in invasion and metastasis. To evaluate the ratio of matriptase/HAI-1 and their potential therapeutic value in ovarian cancer, HO-8910 human ovarian cancer cells and the homologous high-metastatic HO-8910PM cells were used as in vitro cellular models ovarian cancer. The invasive and metastatic abilities, and the expression of matriptase and HAI-1 in these cells were detected using scratch assays, Transwell chamber assays, reverse transcription-quantitative polymerase chain reaction, western blotting and fluorescent immunocytochemistry. Following infection with lentivirus-mediated matriptase-targeting small interfering RNA (siRNA), cell cycle progression and apoptosis were also analyzed. The migration distance and number of invading HO-8910PM cells were significantly increased compared with HO-8910 cells. HO-8910PM cells exhibited a significantly higher ratio of matriptase/HAI-1 mRNA levels compared with HO-8910 cells (0.51 vs. 0.24, 2.2 fold increase). Compared with HO-8910 cells, the matriptase mRNA level was increased by $\sim 3.6$ fold in HO-8910PM cells, whereas the HAI-1 mRNA level was increased by $\sim 1.7$ fold. Similar increases in protein expression levels were also observed in HO-8910PM cells compared with HO-8910 cells. Migration and invasiveness were positively correlated with matriptase expression level $(\mathrm{r}=0.994, \mathrm{P}<0.01)$ and the ratio of matriptase/HAI-1
\end{abstract}

Correspondence to: Professor Pengming Sun, Institute of Gynecologic Oncology, Department of Gynecology, Fujian Maternity and Children Health Hospital, Teaching Hospital of Fujian Medical University, 18 Daoshan Road, Fuzhou, Fujian 350001, P.R. China

E-mail: sunfemy@hotmail.com

Key words: matriptase, HAI-1, ovarian cancer, RNA interference, invasion, metastasis $(\mathrm{r}=0.929, \mathrm{P}<0.01)$. Downregulation of matriptase using siRNA resulted in inhibition of the invasive and metastatic abilities of HO-8910PM cells, cell cycle arrest in the $\mathrm{G}_{0} / \mathrm{G}_{1}$ phase and increased apoptosis. The present study demonstrated that ovarian cancer cell metastasis and invasion were more dependent on upregulation of matriptase levels than downregulation of HAI-1. Matriptase may be a potential adjuvant therapeutic target for inhibiting ovarian cancer invasion and metastasis.

\section{Introduction}

Ovarian cancer is termed 'the silent killer' due to its lack of obvious symptoms. Annually, >225,000 ovarian cancer cases are diagnosed and it causes 125,000 mortalities (1). Ovarian cancer is the most lethal gynecological malignancy in the United States (2). Of the newly diagnosed cases, 70\% are diagnosed at a late stage, for which the 5-year survival rate is $9-35 \%$ (3). For patients with advanced ovarian cancer, metastasis is one of the major causes of treatment failure and mortality (1-3). Thus, researching invasive and metastatic mechanisms is important for improving ovarian cancer-associated survival and cure rates.

Tumor invasion and metastasis are complex biological processes that depend on the matrix-degrading proteolytic system (4,5). Matriptase (also termed suppression of tumorigenicity 14) is a protease that has attracted considerable interest among cancer biologists (6-8). It contains a transmembrane domain, two CUB domains, four low-density lipoprotein-receptor domains and a serine protease domain $(7,9)$. It is expressed in a wide range of epithelial tissues, including the epidermis, gastrointestinal tract and respiratory tract, and in endothelial, neural and white blood cells (10-12).

Currently, few published studies have attempted to address the importance of this protein in ovarian carcinoma. However, there are different conclusions regarding the function of matriptase in ovarian cancer. Tanimoto et al (10) reported that increased matriptase expression is associated with early-stage ovarian cancer and longer patient survival, suggesting that matriptase is a favorable prognostic marker for ovarian cancer. 
Conversely, Jin et al (13) reported that elevated expression of matriptase in serous adenocarcinoma was significantly associated with tumor aggressiveness. The effect of matriptase in ovarian carcinoma remains unclear, and the conflicting conclusions regarding matriptase may be associated with the varying expression of its endogenous inhibitor, hepatocyte growth factor activator inhibitor-1 (HAI-1) (14). Oberst et al (15) demonstrated that an imbalance of matriptase and HAI-1 is observed in advanced ovarian cancer tissues. Furthermore, Vogel et al (16) reported that the matriptase mRNA level was lower in cancer tissues compared with normal tissue from healthy individuals, whereas the ratio of matriptase/HAI-1 mRNA was higher in colorectal cancer adenomas and carcinomas compared with corresponding tissue from control individuals. These previous investigations indicate that the ratio of matriptase/HAI-1 involved in the biological behavior of cancer cell. A previous study demonstrated that the in vitro invasive and metastatic abilities of ovarian cancer cells are correlated with the expression level of matriptase (17). The current study aimed to determine whether this correlation is associated with the expression of matriptase or HAI-1, or with the ratio of matriptase/HAI-1. Furthermore, the study aimed to demonstrate the potential effect of matriptase inhibition as an adjuvant therapeutic.

\section{Materials and methods}

Cells culture. The homologous ovarian cancer cell lines, HO-8910 and HO-8910PM, were purchased from the Type Culture Collection Center of Chinese Academic of Science (Shanghai, China). HO-8910 cells were established by Mou et al (18), and HO-8910PM cells were established by $\mathrm{Xu}$ et al (19). HO-8910PM cells are highly metastatic compared with HO-8910 cells. All cells were cultured in 90\% Dulbecco's modified Eagle's medium (DMEM; Gibco; Thermo Fisher Scientific, Inc., Waltham, MA, USA) supplemented with $10 \%$ fetal bovine serum (Gibco; Thermo Fisher Scientific, Inc.), $1 \%$ penicillin and $1 \%$ streptomycin $(100 \mathrm{IU} / \mathrm{ml})$ in a $37^{\circ} \mathrm{C}$ incubator with $5 \% \mathrm{CO}_{2}$. The study was approved by the ethics committee of Fujian Maternity and Children Health Hospital (Fujian, China).

Reverse transcription-quantitative polymerase chain reaction (RT-qPCR). Total RNA was isolated according to the TRIzol reagent (Invitrogen; Thermo Fisher Scientific, Inc.). Only mRNA samples with an optical density 260/280 ratio $>1.8$ were used in the experiments, this was determined using a Nanodrop 2000 (Thermo Fisher Scientific, Inc.). The Access RT-PCR system (Promega Corporation, Madison, WI, USA) was used according to the manufacturer's protocol. The cDNA (2 $\mu \mathrm{l})$ was used for qPCR. RT-qPCR was performed using LightCycler 480 SYBR Green I Master Mix (Roche Diagnostics $\mathrm{GmbH}$, Mannheim, Germany) according to the instructions. The cycling protocol for qPCR was as follows: $95^{\circ} \mathrm{C}$ for $15 \mathrm{sec} ; 95^{\circ} \mathrm{C}$ for $5 \mathrm{sec}$ and $60^{\circ} \mathrm{C}$ for $20 \mathrm{sec}, 45$ cycles; $95^{\circ} \mathrm{C}$ for $1 \mathrm{~min}$, cooling to $55^{\circ} \mathrm{C}$. The following primers were synthesized by Takara Biotechnology Co., Ltd. (Dalian, China): Matriptase, sense 5'-TCGTCACTTGTACCAAAC ACACCTA-3', antisense 5'-GAGCCTGTCTCGTGAA TGACC-3'; HAI-1, sense 5'-GGCAACAAGAACAACTTT
GAGGA-3', anti-sense 5'-CAATGCAGATGACCAGGA ACAC-3'. The GAPDH primers were purchased from Takara Biotechnology Co., Ltd. (cat. no. HA067812; GenBank accession no. NM_002046). The PCR products were 150 bp in length for matriptase, $154 \mathrm{bp}$ for HAI-1 and $138 \mathrm{bp}$ for GADPH. The relative mRNA levels were calculated using the comparative cycle threshold $(\mathrm{Cq})$ method $(\Delta \Delta \mathrm{Cq})(20)$.

Fluorescent immunocytochemistry. Cells were seeded at $1.0 \times 10^{5}$ cells/well were seed on the glass coverslips then placed in a 12-well-plate, and cultured overnight. The cells were rinsed with phosphate-buffered saline (PBS), and fixed with $4 \%$ paraformaldehyde for $10 \mathrm{~min}$, followed by goat serum (OriGene Technologies, Inc., Beijing, China)blocking for $30 \mathrm{~min}$. Next, the cells were incubated with rabbit-anti-matripase polyclonal antibody (cat. no. ab28266; 1:500; Abcam, Cambridge, UK) at $4^{\circ} \mathrm{C}$ for overnight. Subsequent to incubation, cells were rinsed with PBS twice and incubated with FITC-labeled goat-anti-rabbit antibody (cat. no. BA1110; 1:50; Boster Bio, Wuhan, China) for $1 \mathrm{~h}$. To detect the nucleus of cells, they were washed by PBS for $5 \mathrm{~min}$, and cell nuclei were stained with 4',6-diamidino-2phenylindole at 1:1000 dilution for $5 \mathrm{~min}$. Serum-free DMEM medium was used as a negative control. Subsequent to the discarding of the medium, the cells were analysed using a confocal scanning microscope (Leica Microsystems GmbH, Solms, Germany). The image was analysed by LAS AF lite software (21). For the slides, each quadrant section and the middle section (3 fields in total) were observed at random at magnification, $\mathrm{x}$ 100, 20 cells/field were used to calculate the intensity of green fluorescence signal and recorded as the mean \pm standard deviation (21).

Cellular scratch assay. The horizontal migration of cells was assessed by a scratch assay (22). Cells were seeded at a density of $5.0 \times 10^{5}$ cells/well, then imaged at $\mathrm{x} 40$ magnification with an Olympus IX70 inverted fluorescence microscope (Olympus Corporation, Tokyo, Japan) at 0 and $24 \mathrm{~h}$ post-scratching. Image ProExpress C software 5.1 (Olympus Corporation) was used to measure the change of the cell distance between the scratches. The average horizontal migration rate was calculated using the following formula: $\left(\right.$ Width $_{0 \mathrm{~h}}$-width $_{24 \mathrm{~h}}$ )/width ${ }_{0 \mathrm{~h}}$ x 100 .

Transwell chamber assay. The cellular invasive capacity was determined using the Matrigel invasion chamber assay as previous reported (23). Cells were seeded at a density of $5.0 \times 10^{5}$ cells/well. The number of cells on the underside of the filter was determined by counting cells in 5 random fields from 3 filters for each treatment at x 200 magnification with an inverted microscope (Olympus Corporation).

Western blotting. Whole-cell protein was extracted according to the protocol provided with the Pierce BCA Protein Assay kit (Thermo Fisher Scientific, Inc.). The protein content was determined using an enzyme-linked immunosorbent assay. Whole-cell protein $(100 \mu \mathrm{g})$ was loaded on an $8 \%$ polyacrylamide gel. Proteins were blotted onto nitrocellulose membranes. The blots were washed in phosphate-buffered saline (PBS) and incubated in blocking buffer [1X PBS, $0.1 \%$ Tween-20, 5\% I-Block (Thermo Fisher Scientific, Inc.)] at $20^{\circ} \mathrm{C}$ for $1 \mathrm{~h}$. Membranes were incubated overnight at 
$20^{\circ} \mathrm{C}$ with a polyclonal rabbit matriptase antibody $(1: 1,000$ dilution; cat. no. ab28266; Abcam) or a monoclonal rabbit HAI-1 antibody (1:2,000 dilution; cat. no. ab189511; Abcam) in blocking buffer, followed by incubation with an alkaline phosphatase-conjugated anti-rabbit secondary antibody (cat. no. BA0632; 1:1,000; Boster Bio) at room temperature for $10 \mathrm{~min}$. Bands were visualized using the CDP-Star luminescence system (Sigma-Aldrich, St. Louis, MO, USA).

Lentivirus-mediated small interfering RNA (siRNA) construction and infection. Three pairs of complementary oligonucleotides target matriptase gene (GenBank accession no. NM_021978) were designed as follows: Ma-siRNA-1, CCG GCTTCTTAGCTGAATA; Ma-siRNA-2, TGTCCAGAA GGTCTTCAAT; and Ma-siRNA-3, ACGAGAAAGTGGAAT GGCTT. These stem-loop oligonucleotides were synthesized and cloned into a lentivirus-based vector carrying the green fluorescent protein (GFP) gene (cat. no. GV115; GeneChem Co., Ltd., Shanghai, China). A universal sequence (TTCTCC GAACGTGTCACGT) was used as a negative control (NC) for RNA interference. The siRNA and NC lentiviral constructs were prepared as previously described (24) and used to infect HO-8910PM cells at multiplicities of infection (MOIs) of 20 (low) and 80 (high). The siRNA with the highest silencing efficiency was used for subsequent experiments.

Cellular DNA and apoptosis analysis. For flow cytometric analysis, the harvested cell pellets of HO-8910PM, and transfected HO-8910PM-NC and HO-8910PM-SI were fixed with pre-cooled $70 \%$ ethanol and stained with propidium iodide $\left(100 \mu \mathrm{g} / \mathrm{ml}\right.$ RNase in PBS) at $37^{\circ} \mathrm{C}$ for $30 \mathrm{~min}$. The cell cycle distribution was then determined as previously described (25). Apoptosis was detected using the Annexin-V-FLUOS staining kit (Roche Diagnostics $\mathrm{GmbH}$ ) according to the manufacturer's protocol. Fluorescein was measured using a FACSCanto II flow cytometer (BD Biosciences, Franklin Lakes, NJ, USA).

Statistical analysis. All the experiments were performed in triplicate. Statistical analyses were performed using the average results of three repeated experiments under identical conditions. Numerical data are presented as the mean \pm standard deviation. The differences between two means were compared by Student's t-test and related parameters were analyzed using Pearson's correlation analysis. A one-way analysis of variance was used for multiple comparisons of groups. Data were analyzed using SPSS software 15.0 for Windows (SPSS Inc., Chicago, IL, USA). $\mathrm{P}<0.05$ was considered to indicate a statistically significant difference.

\section{Results}

Different invasive and metastatic activity in HO-8910 and HO-8910PM cells. A pair of syngeneic human epithelial ovarian cancer cells, HO-8910 and HO-8910PM, were used as in vitro cellular models of ovarian cancer. Following scratching and incubation for $24 \mathrm{~h}$, the mean migration distance of HO-8910PM cells was significantly higher compared with HO-8910 cells $(347.23 \pm 8.41 \mu \mathrm{m}$ vs. $153.95 \pm 9.56 \mu \mathrm{m} ; \mathrm{P}<0.01$; Fig. 1A). Additionally, in the invasion assay, after incubation for $24 \mathrm{~h}$, the number of cells that migrated through the Transwell membrane was significantly higher for HO-8910PM cells compared with HO-8910 cells $(90.67 \pm 2.08$ vs. 63.33 \pm 1.52 ; $\mathrm{P}<0.01$; Fig. 1B).

Expression of matriptase and HAI-1, and the ratio of matriptase/HAI-1 in HO-8910 and HO-8910PM cells. The mRNA expression levels of matriptase and HAI-1 were higher in HO-8910PM cells compared with HO-8910 cells $(0.446 \pm 0.03$ vs. $0.124 \pm 0.03, \mathrm{P}<0.01$ and $0.863 \pm 0.03$ vs. $0.519 \pm 0.03, \mathrm{P}<0.01$, respectively; Fig. 2A) as measured by RT-qPCR. The mRNA level of matriptase was increased by $\sim 3.6$ fold and the mRNA level of HAI-1 was increased by $\sim 1.7$ fold in HO-8910PM compared with HO-8910 cells. The mRNA ratio of matriptase/HAI-1 was increased from 0.24 in $\mathrm{HO}-8910$ cells to 0.52 in HO-8910PM ( $\mathrm{P}<0.01 ; \sim 2.2$ fold increase). Immunocytochemistry demonstrated that the matriptase protein is predominantly localized in the cytoplasm and at the cell membrane (Fig. 2B). Additionally, compared with HO-8910 cells, stronger signal intensity $(15.63 \pm 0.83$ vs. $7.65 \pm 1.30 ; \mathrm{P}<0.01$; Fig. $2 \mathrm{~B})$ and higher protein expression levels of matriptase and HAI-1 $(0.25 \pm 0.13$ vs. $0.11 \pm 0.02$, and $0.54 \pm 0.16$ vs. $0.46 \pm 0.12 ; \mathrm{P}<0.01$; Fig 2C) were detected in HO-8910PM cells. The protein level of HAI-1 was increased by 2.3 fold in HO-8910PM compared with HO-8910 cells, and the protein of HAI-1 was increased by $\sim 1.2$ fold. The protein ratio of matriptase/HAI-1 was increased from 0.24 in HO-8910 cells to 0.47 in HO-8910PM cells ( 1.9 fold increase).

Association of invasive and metastatic activity with the expression of matriptase. To evaluate the potential association of matriptase expression with the invasive and metastatic activity of ovarian cancer cells, Pearson's correlation analysis was performed. The metastasis and invasiveness of the ovarian cancer cells were positively correlated with matriptase mRNA expression levels ( $r=0.994$ and $r=0.965$, respectively; $\mathrm{P}<0.01$ ) and matriptase protein expression levels $(r=0.976$ and $r=0.961$, respectively; $\mathrm{P}<0.05)$. The metastasis and invasiveness were also positively correlated with the ratio of matriptase/HAI-1 $(r=0.929$ and $r=0.912$, respectively; $\mathrm{P}<0.01)$. However, metastasis and invasion were not significantly correlated with the expression of HAI-1 ( $\mathrm{P}>0.05)$.

Suppression of matriptase expression in HO-8910PM cells. Three lentivirus-mediated siRNAs targeting matriptase were constructed and used to infect HO-8910PM cells at high and low MOIs (Fig. 3A). Compared with NC, matriptase mRNA levels in HO-8910PM cells were decreased by $19.63,89.72$ and $32.43 \%$ by Ma-siRNA-1, Ma-siRNA-2, and Ma-siRNA-3, respectively (Fig. 3B). Additionally, western blot analysis demonstrated that Ma-siRNA-2 significantly reduced the matriptase protein expression level compared with $\mathrm{NC}$ $(\mathrm{P}<0.01$; Fig. $3 \mathrm{C})$. The siRNA inhibited matriptase expression but did not affect HAI-1 levels. The HO-8910PM cells infected with Ma-siRNA-2, which induced the greatest inhibition of matriptase levels, were termed HO-8910PM-SI2 and selected for further analysis.

Inhibition of the invasiveness and metastatic ability of HO-8910PM cells by downregulation of matriptase. The invasiveness and metastatic ability of HO-8910PM-SI2 cells 
A
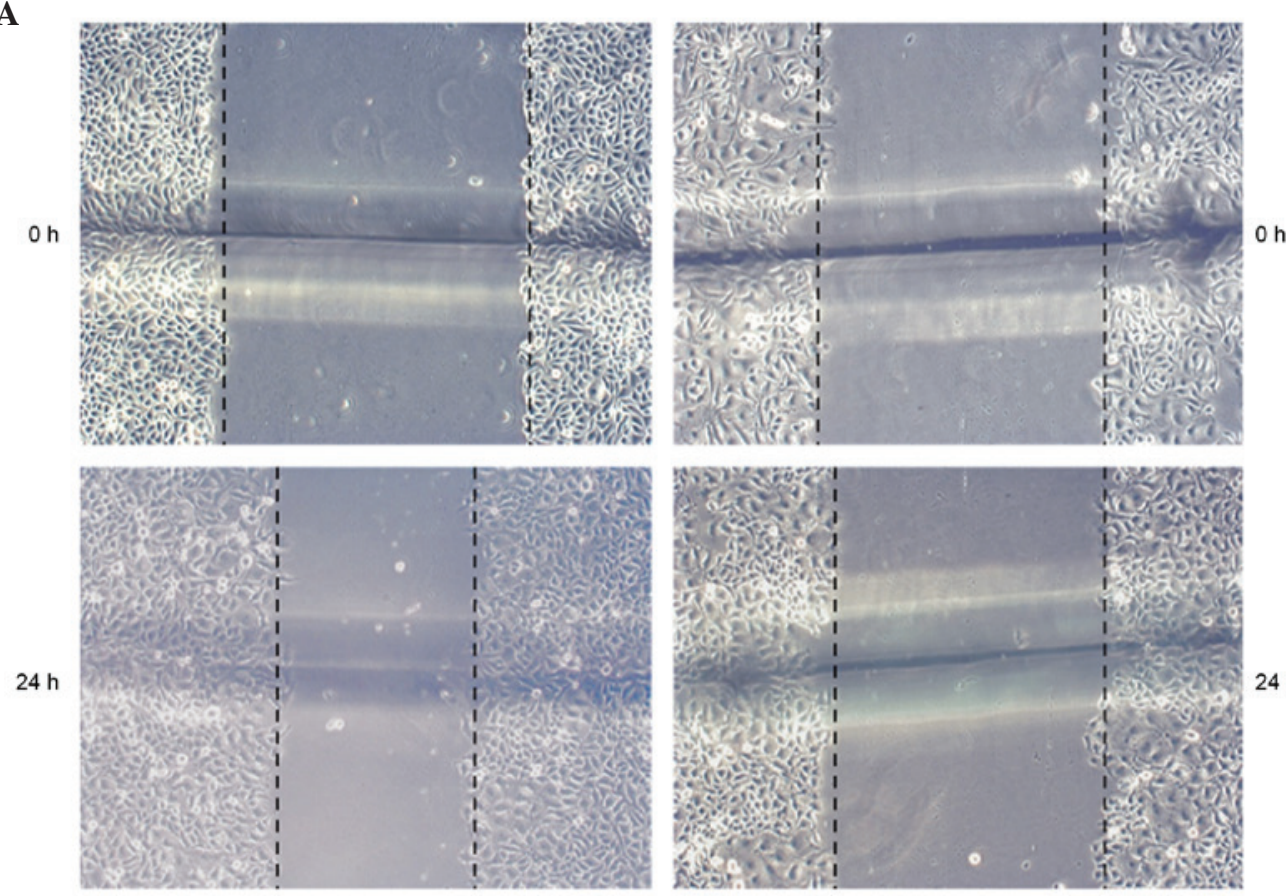

HO-8910 PM

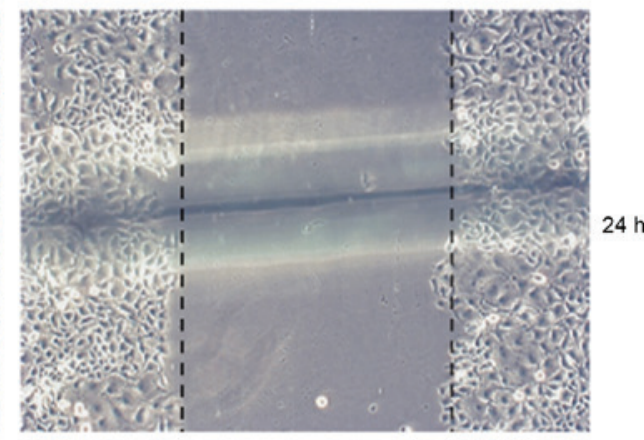

HO-8910

B
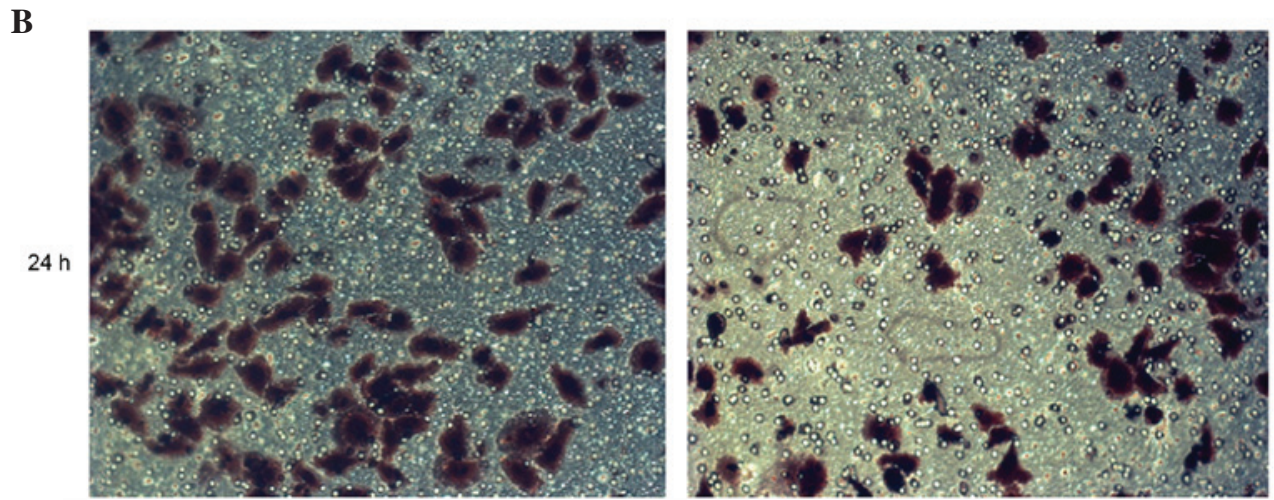

$24 \mathrm{~h}$
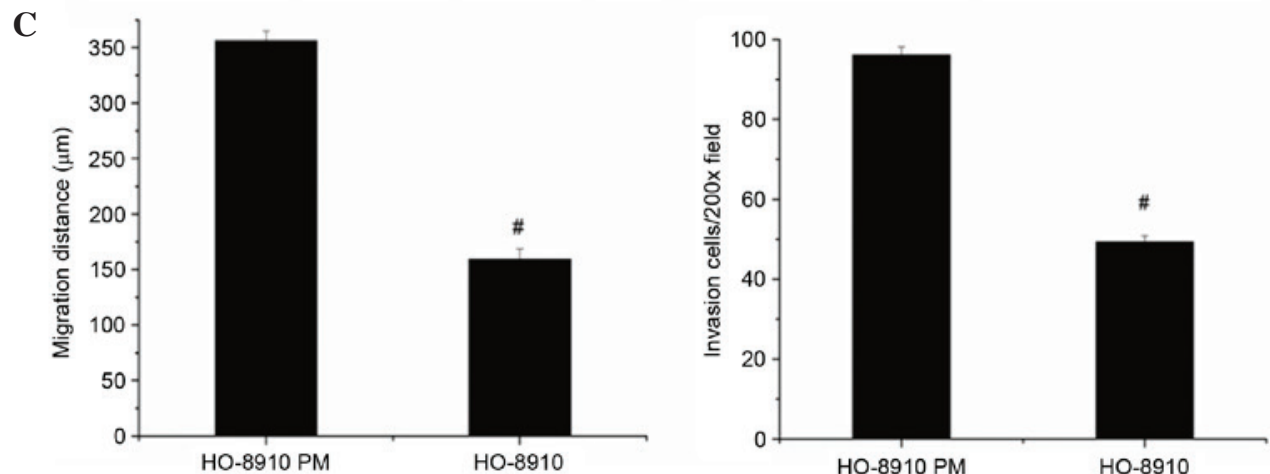

Figure 1. Metastasis and invasiveness of HO-8910 and HO-8910PM ovarian cancer cells. HO-8910PM cells demonstrate higher metastatic and invasive abilities compared with HO-8910 cells. (A) Following scratching and $24 \mathrm{~h}$ incubation, the migration distance of HO-8910PM cells was increased compared with HO-8910 cells. (B) Following incubation for 24 h, significantly more HO-8910PM cells penetrated the Transwell membrane compared with HO-8910 cells. (C) Quantification of migration and invasion of HO-8910 and HO-8910PM cells. " $\mathrm{P}<0.05$ vs. HO-8910. Values are presented as the mean \pm standard deviation.

were compared with HO-8910PM, HO-8910PM-NC, and HO-8910 cells. The number of HO-8910PM-SI2 cells $(38.33 \pm 3.51)$ that penetrated the Transwell chamber membrane was significantly reduced compared with HO-8910PM (100.00 \pm 4.36$)$, HO-8910PM-NC (92.67 \pm 2.52$)$, and HO- 8910 cells $(62.33 \pm 3.06$, all $\mathrm{P}<0.01$, Fig. $4 \mathrm{~A})$. Additionally, the $24-\mathrm{h}$ migration distances of HO-8910PM-SI2 cells $(104.33 \pm 7.07 \mu \mathrm{m})$ were significantly reduced compared with HO-8910PM (394.08 $\pm 8.20 \mu \mathrm{m}), \mathrm{HO}-8910 \mathrm{PM}-\mathrm{NC}(387.44 \pm 2.76 \mu \mathrm{m})$ and HO-8910 cells (198.80 $\pm 10.46 \mu \mathrm{m}$; all $\mathrm{P}<0.01$; Fig. 4B).

Matriptase suppression induces apoptosis in HO-8910 and HO-8910PM cells. The percentage of $\mathrm{G}_{0} / \mathrm{G}_{1}, \mathrm{~S}$ and $\mathrm{G}_{2} / \mathrm{M}$ phase HO-8910PM-SI2 cells were $54.81,41.03$ and 
A

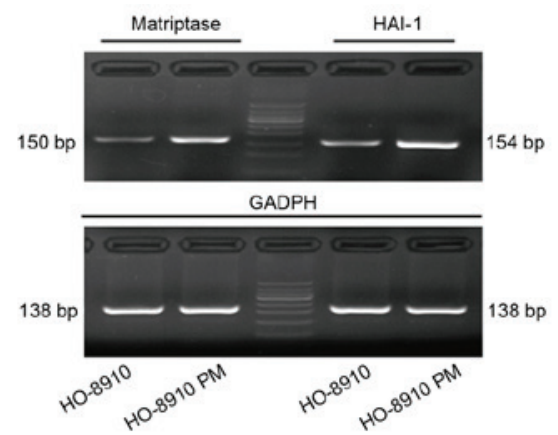

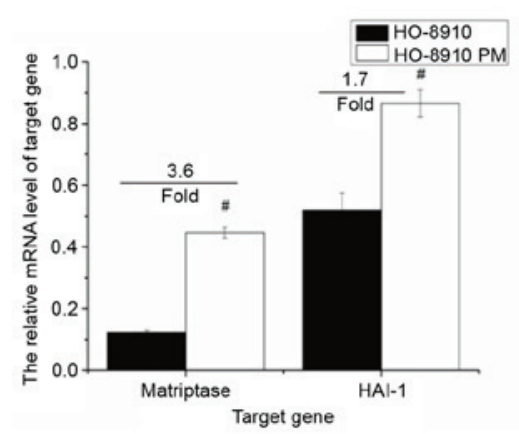

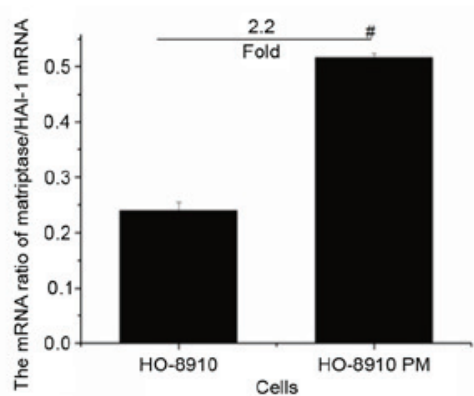

B

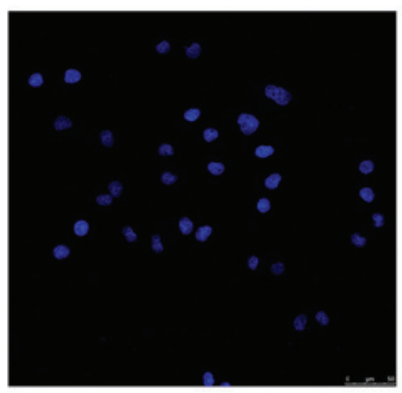

HO-8910-DAPI

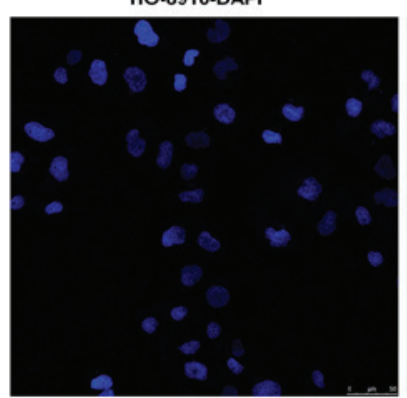

HO-8910PM-DAPI

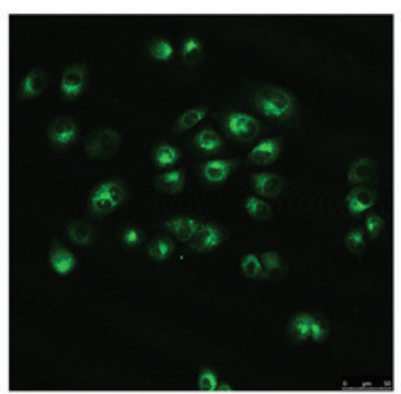

HO-8910-FITC

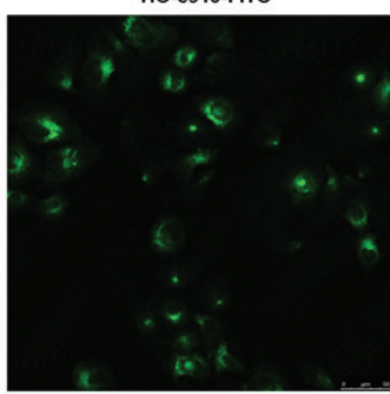

HO-8910PM-FITC
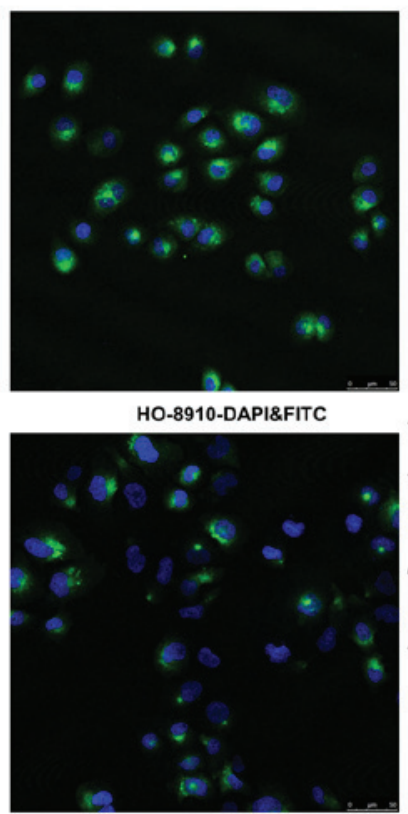

HO-8910PM-DAPI\&FITC

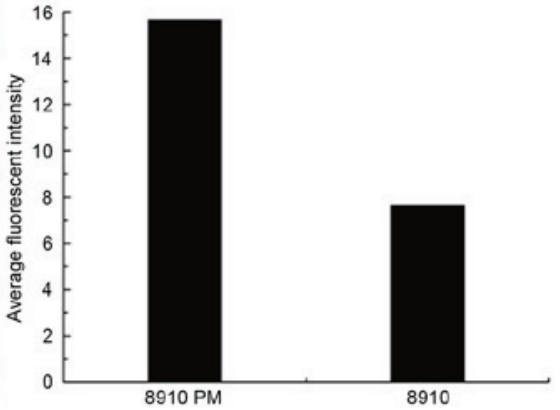

C

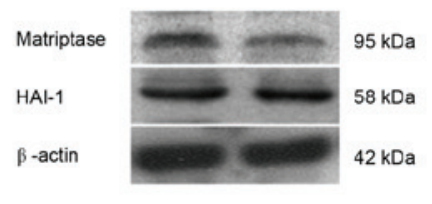

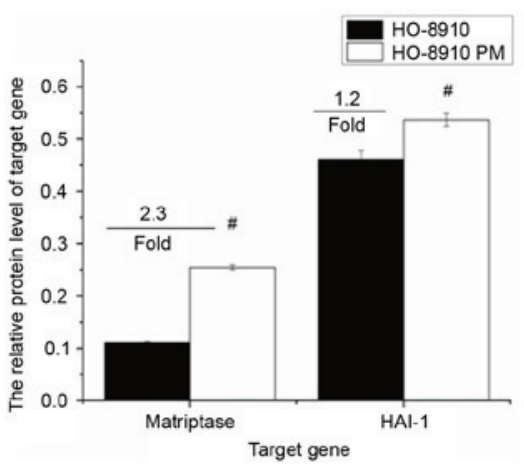

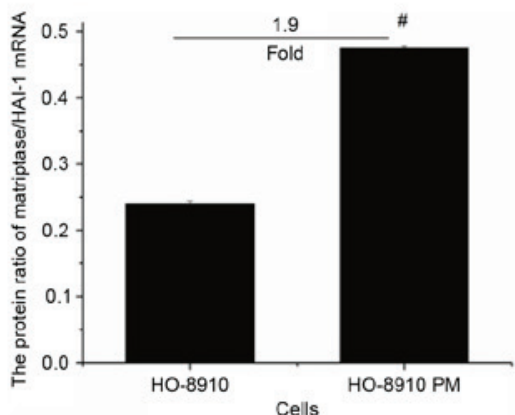

Figure 2. Expression of matriptase and HAI-1 in HO-8910 and HO-8910PM ovarian cancer cells was detected $24 \mathrm{~h}$ after the infection with lentivirus. (A) The relative mRNA levels of matriptase and HAI-1 were higher in HO-8910PM cells compared with HO-8910 cells as detected by reverse transcription-quantitative polymerase chain reaction. Matriptase mRNA level was $~ 3.6$-fold higher in HO-8910PM, while HAI-1 mRNA was $\sim 1.7$-fold higher compared with HO-8910 cells. (B) The matriptase protein was primarily detected in the cytoplasm of ovarian cancer cells. Magnification, x400. A stronger intensity green staining was observed in HO-8920PM cells compared to HO-8910 cells. Under x400 magnification, the average intensity of the green signal was significantly higher in HO-8910PM compared with HO-8910 cells ( $15.63 \pm 0.83$ vs. $7.65 \pm 1.30, t=8.959, \mathrm{P}=0.001, \sim 2$-fold). (C) Matriptase protein expression was higher in HO-8910PM compared with HO-8910 cells as detected by western blotting. Matriptase protein levels were increased 2.3-fold in HO-8910PM, while HAI-1 protein levels increased $\sim 1.2$-fold, compared with HO-8910 cells. There was a 1.9-fold increase in matriptase/HAI-1 mRNA expression ratio in HO-8910PM cells (0.51) compared with HO-8910 cells (0.24). ${ }^{~} \mathrm{P}<0.05$ vs. HO-8910. HAI-1, hepatocyte growth factor activator inhibitor-1.

$4.16 \%$, respectively. The number of matriptase-knockdown HO-8910PM-SI2 cells in the $\mathrm{G}_{0} / \mathrm{G}_{1}$ phase $(54.81 \pm 0.34 \%)$ was significantly increased compared with HO-8910PM-NC
$(43.08 \pm 0.47 \%)$ and HO- $8910 \mathrm{PM}$ cells $(42.73 \pm 0.39 \%$; both $\mathrm{P}<0.01$; Fig. $5 \mathrm{~A})$. Whereas, the number of $\mathrm{G}_{2} / \mathrm{M}$ phase HO-8910PM-SI2 cells $(4.16 \pm 0.74 \%)$ was significantly 
A

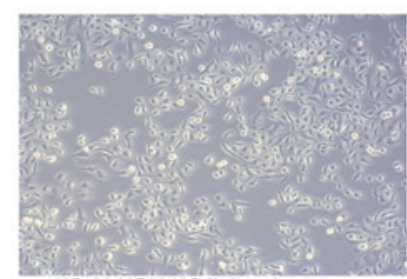

HO-8910PM-NC light microscope

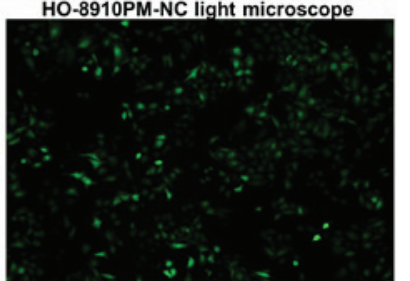

HO-8910PM-NC at low MOI

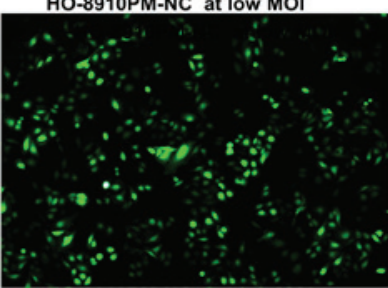

HO-8910PM-NC at high MOI
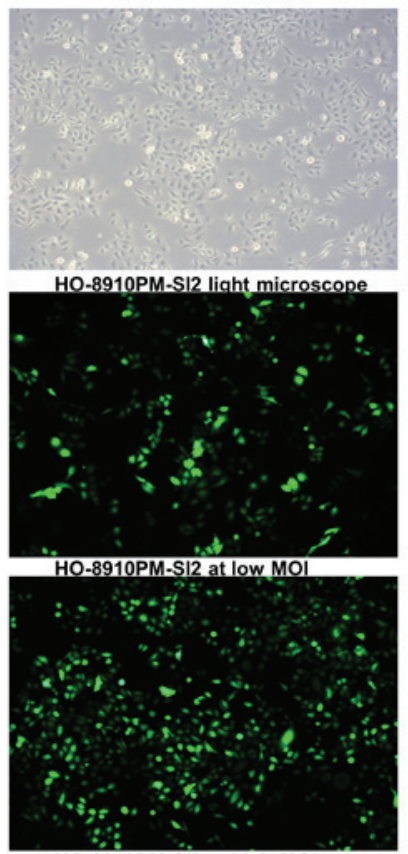

HO-8910PM-SI2 at high MOI
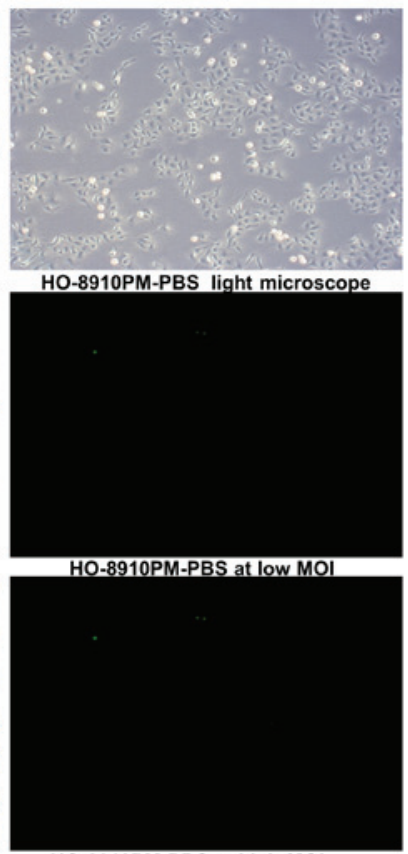

HO-8910PM-PBS at high MOI
B

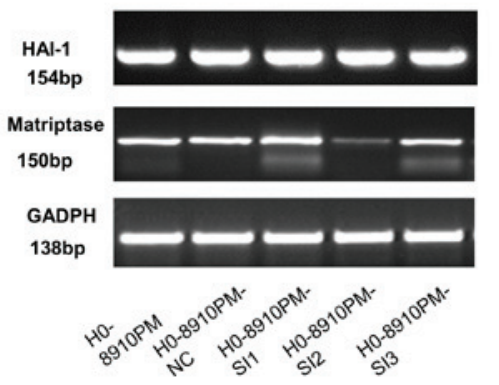

C

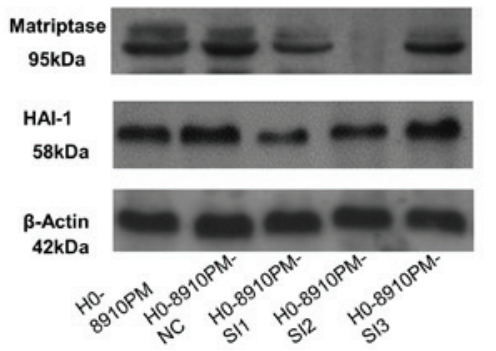

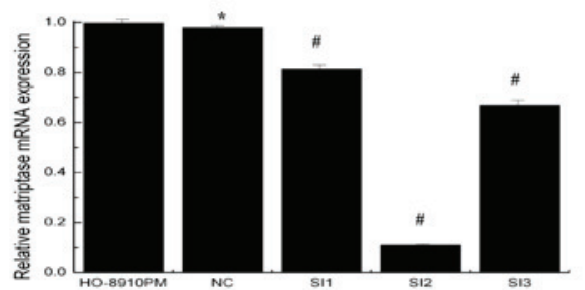
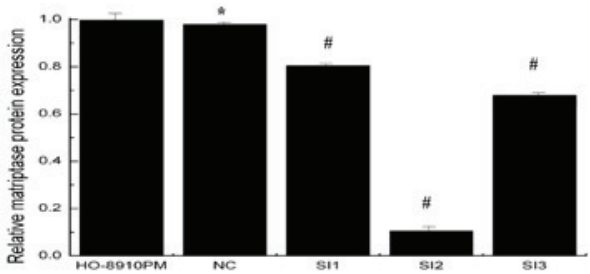

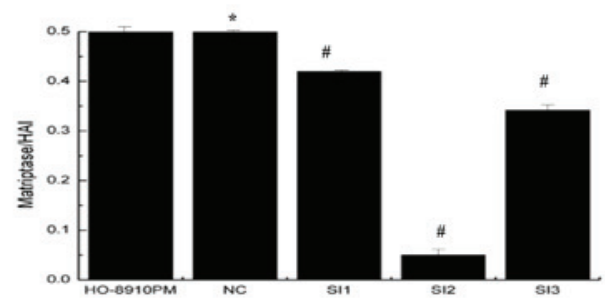

Figure 3. Downregulation of matriptase expression by RNA interference. (A) Microscopic examination of the infection efficiencies of different lentiviral-mediated SI constructs targeting matriptase in HO-8910PM cells (magnification, x100). There was no signal observed in HO-8910PM-PBS. The infection efficiencies exceeded $80 \%$ at a MOI of 80. (B) Relative matriptase mRNA expression levels in HO-8910PM cells infected with different lentiviral particles at high MOI. Matriptase SI2 achieved the highest inhibition of matriptase mRNA expression, and little inhibition was observed in HO-8910PM-NC cells. The SI inhibited matriptase expression but not HAI-1 expression. The ratio of matriptase/HAI-1 was significantly reduced in the HO-8910PM cells treated with matriptase SI2. (C) Relative matriptase protein expression levels in HO-8910PM cells transfected with different lentiviral particles at high MOI. Protein quantification was normalized using $\beta$-actin. The highest silencing efficiency was achieved in HO-8910PM-SI2 cells using matriptase SI2. ${ }^{*} \mathrm{P}>0.05$ vs. HO-8910PM; ${ }^{*} \mathrm{P}<0.05$ vs. HO-8910PM. MOI, multiplicity of infection; HAI-1, hepatocyte growth factor activator inhibitor-1; NC, negative control; SI, small interfering RNA.

reduced compared with $\mathrm{HO}-8910 \mathrm{PM}-\mathrm{NC}(17.65 \pm 0.63 \%)$ and HO-8910PM (8.35 $\pm 0.65 \%$; both $\mathrm{P}<0.01)$. However, no significant difference in $\mathrm{S}$ phase content was observed between the HO-8910PM-SI2, HO-8910PM-NC and HO-8910PM cells $(41.03 \pm 1.02,39.27 \pm 0.97$, and $38.92 \pm 1.12 \%$, respectively). Furthermore, matriptase suppression decreased the percentage of surviving cells and increased the percentage of early apoptotic cells (Fig. 5B). Compared with HO-8910PM-NC
(88.7 $\pm 0.41 \%)$ and HO-8910PM cells $(86.2 \pm 0.41 \%)$, the number surviving HO-8910PM-SI2 cells of was significantly lower (75.10 $\pm 0.41 \% ; \mathrm{P}<0.01)$. Additionally, the number of early apoptotic HO-8910PM-SI2 cells $(15.10 \pm 0.81 \%)$ was significantly increased compared with HO-8910PM-NC $(5.2 \pm 0.39 \%)$ and HO-8910PM cells $(5.3 \pm 0.33 \%$; both $\mathrm{P}<0.01)$. The percentages of late apoptotic and necrotic cells were not significantly different between the cells. 
A
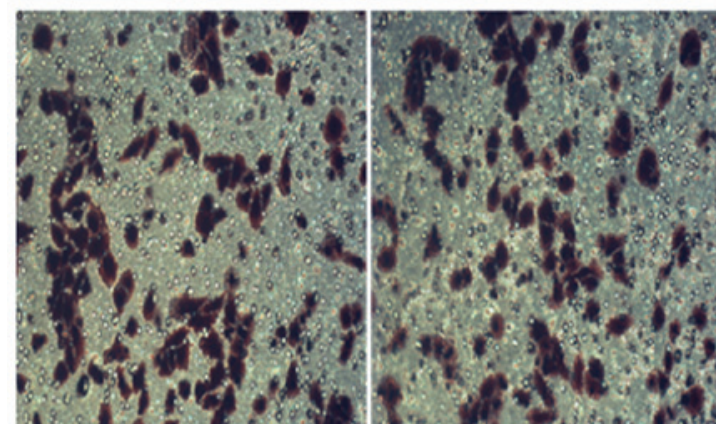

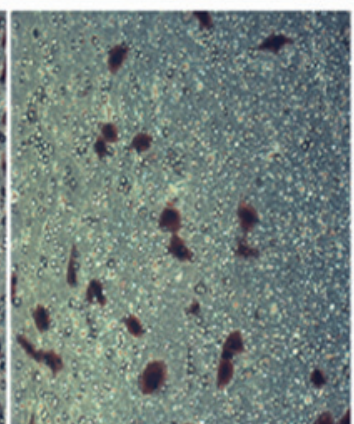

HO-8910 PM-SI2

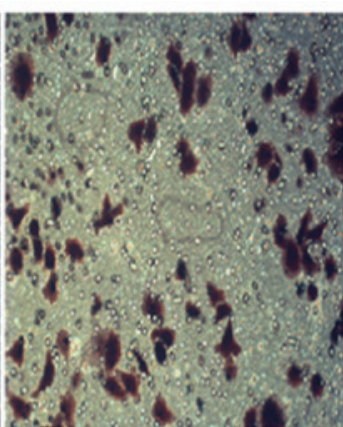

HO-8910

B
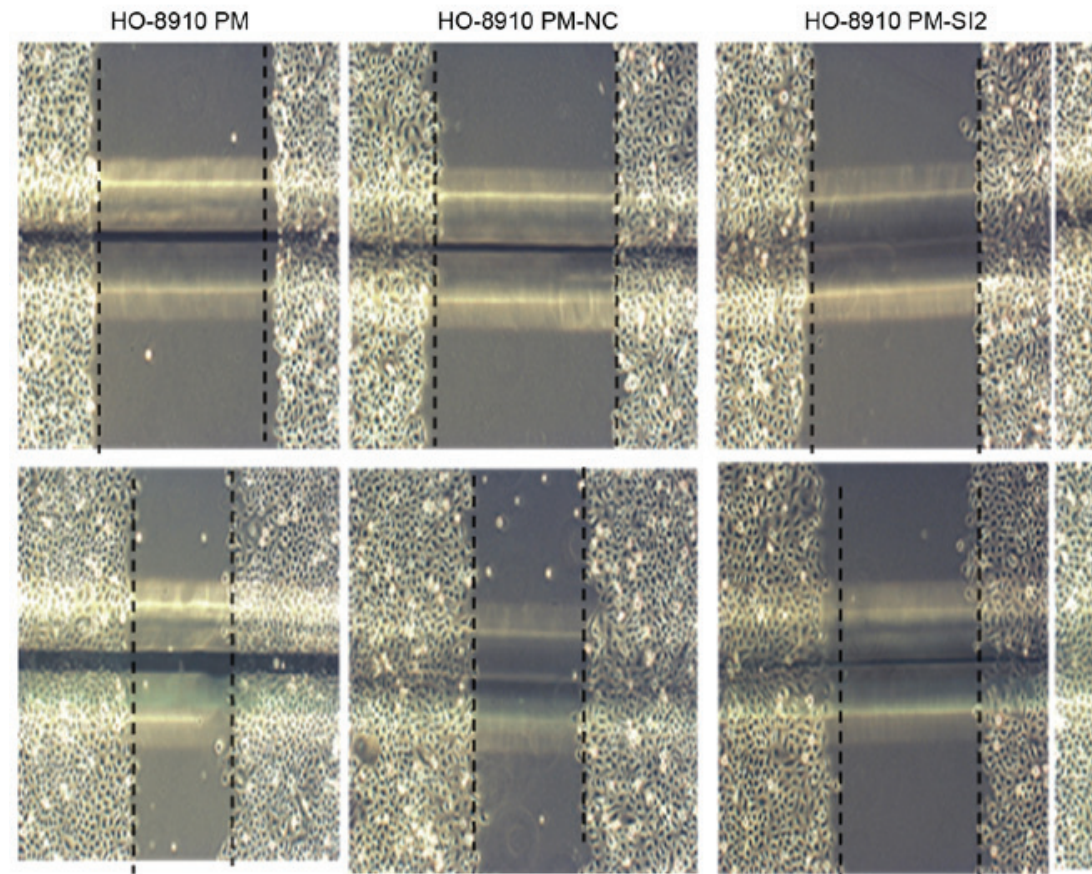

HO-8910

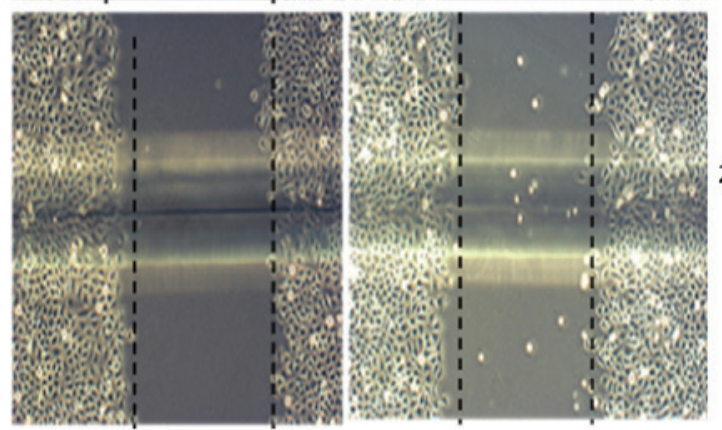

C

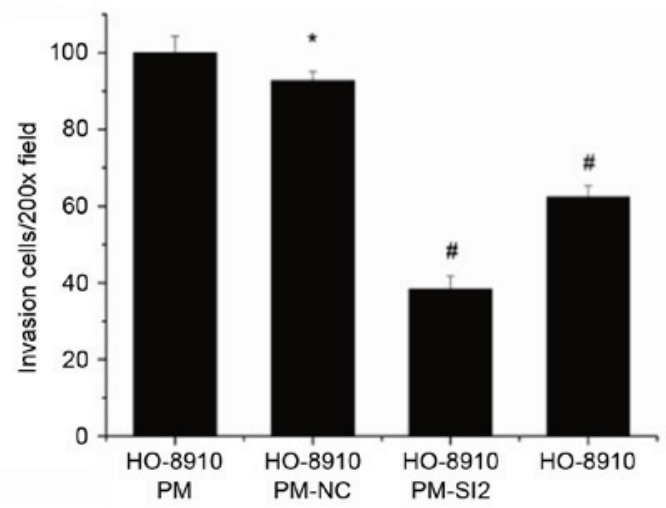

D

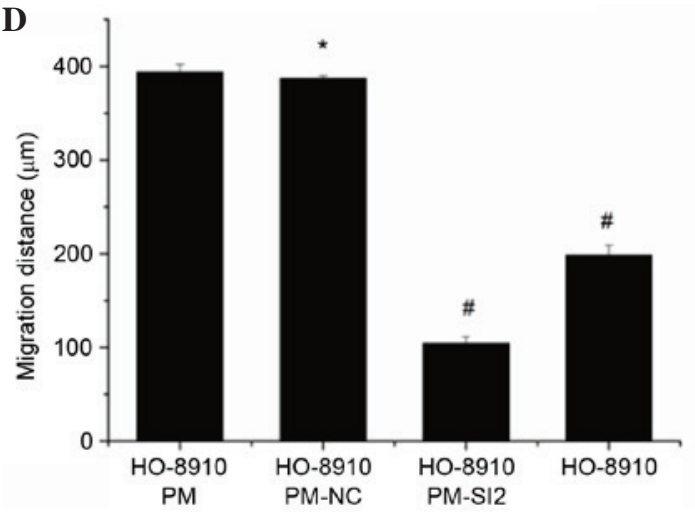

Figure 4. Inhibition of the invasiveness and metastatic ability of ovarian cancer cells via matriptase suppression. (A) Invasion and (B) migration were measured by Transwell and scratch assays, respectively. Magnification, x200. (C) The number of HO-8910PM-SI2 cells that migrated through the Transwell membrane was significantly lower $(38.33 \pm 3.51)$ compared with HO-8910PM $(100.00 \pm 4.36, \mathrm{P}<0.01)$, HO-8910PM-NC $(92.67 \pm 2.52$, P $<0.01)$, and HO-8910 cells $(62.33 \pm 3.06, \mathrm{P}<0.01)$. The number of HO-8910PM-NC cells and HO-8910PM cells that migrated through the Transwell membrane was not significantly different $(\mathrm{P}=0.185)$. (D) Scratch assay results indicated that matriptase depletion significantly decreased the migratory ability of HO-8910PM cells $(\mathrm{P}<0.01)$ Compared with that of HO-8910PM-SI2 cells $(104.33 \pm 7.07 \mu \mathrm{m})$, the 24-h migration distances of HO-8910PM (394.08 $\pm 8.20 \mu \mathrm{m}, \mathrm{P}<0.01)$, HO-8910PM-NC $(387.44 \pm 2.76 \mu \mathrm{m}, \mathrm{P}<0.01)$ and HO-8910 cells $(198.80 \pm 10.46 \mu \mathrm{m}, \mathrm{P}<0.01)$ were significantly increased. " $\mathrm{P}>0.05$ vs. HO-8910PM; ${ }^{*} \mathrm{P}<0.05$ vs. HO-8910PM. $\mathrm{NC}$, negative control; SI, small interfering RNA.

\section{Discussion}

Despite clinical effort, metastatic ovarian cancer often inevitably progresses to eventually cause mortality (25). Several previous reports suggest that matriptase is involved in the initiation of epithelial cell carcinogenesis (12,26-28). Furthermore, matriptase may also be important for cell invasiveness and metastasis $(29,30)$. In the current study, the human ovarian cancer cell HO-8910 and its homologous highly metastatic clone HO-8910PM were used to assess the 
A

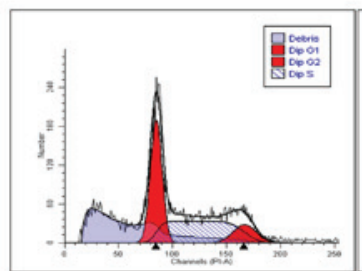

HO-8910PM

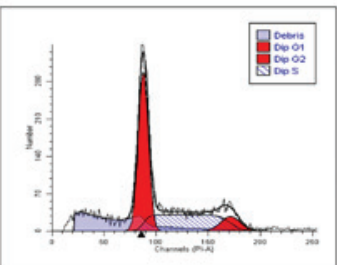

HO-8910PM-NC

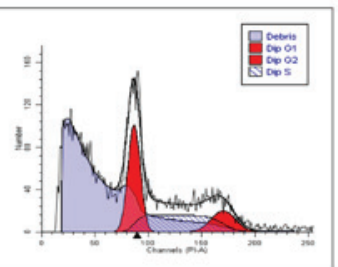

HO-8910PM-SI2

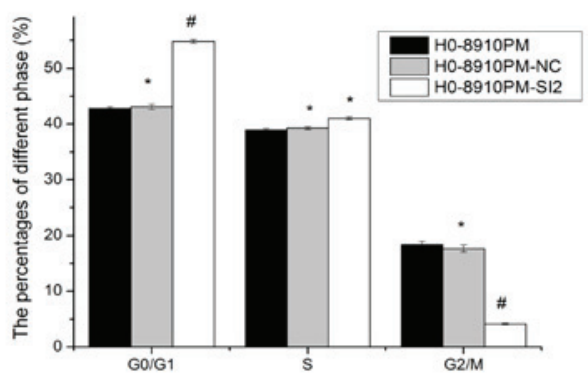

B
HO-8910 PM

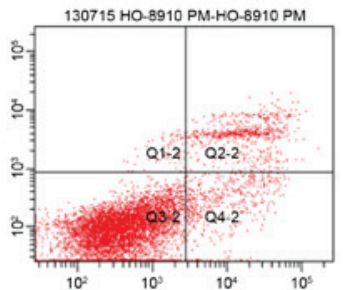

HO-8910 PM-NC

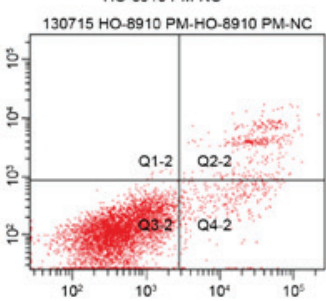

HO-8910 PM-SI2

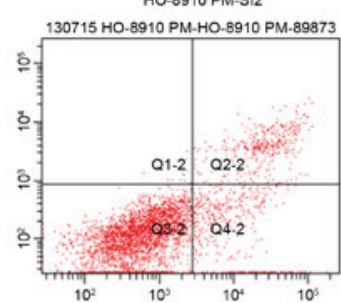

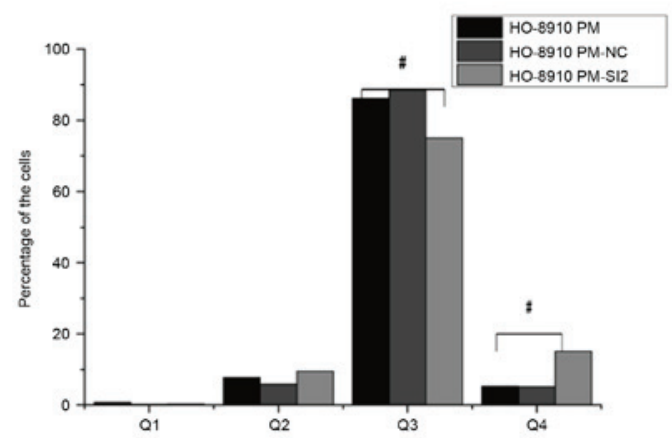

$\mathbf{C}$
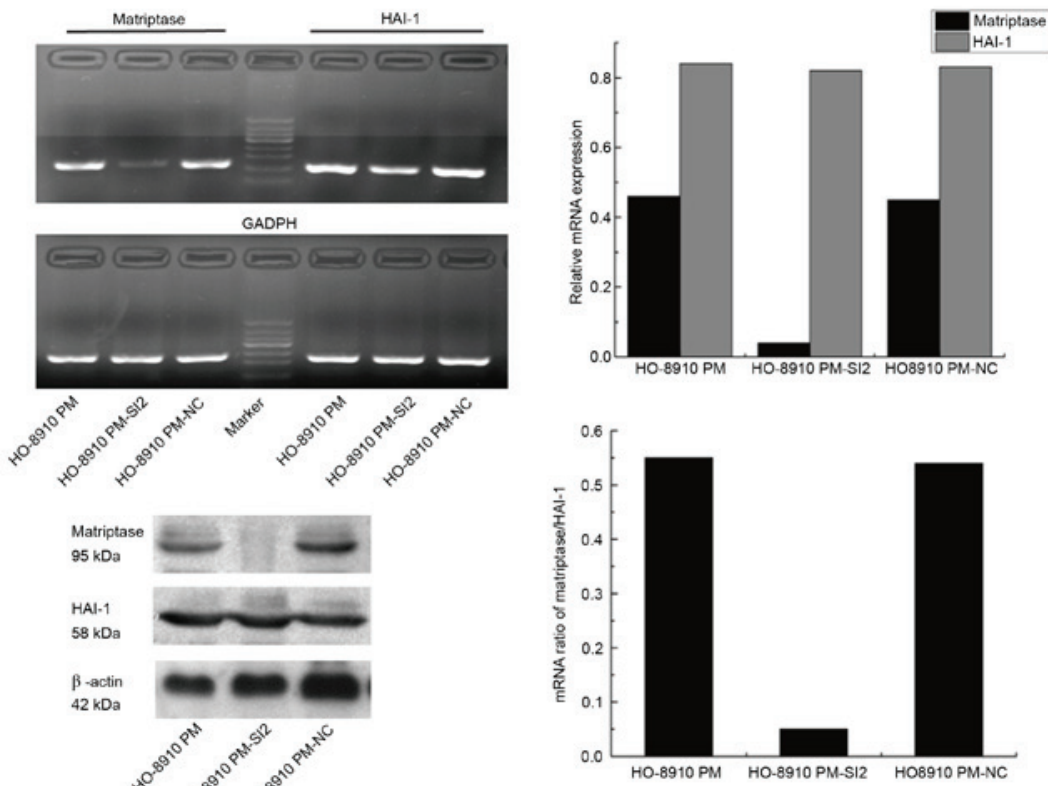

Figure 5. Downregulation of matriptase results in cell cycle arrest and increased apoptosis in HO-8910PM cells. (A) Flow cytometry analysis demonstrated that the percentage of cells in the G1/G0 phase was significantly higher for matriptase-depleted HO-8910PM-SI2 cells than for HO-8910PM-NC and HO-8910PM cells $(42.73 \pm 0.39 \%, \mathrm{P}<0.01)$. Tthe percentage of HO-8910PM-SI2 cells in the G2/M phase was significantly lower (4.16 $\pm 0.74 \%)$ than that of HO-8910PM-NC $(17.65 \pm 0.63 \%, \mathrm{P}<0.01)$ and $\mathrm{HO}-8910 \mathrm{PM}$ cells $(18.35 \pm 0.65 \%, \mathrm{P}<0.01)$. Conversely, no differences in $\mathrm{S}$ phase content were noted among the 3 cell lines. (B) Matriptase depletion significantly decreased the percentage of surviving cells and increased the percentage of early apoptotic cells in HO-8910PM-SI2 cells compared with the negative control and wild type cells. The percentages of late apoptotic and necrotic cells were not significantly different. (C) Relative mRNA and protein expression levels of matriptase and HAI-1 were detected in HO-8910PM, HO-8910PM-SI2 and HO-8910PM-NC cells. The highest silencing efficiency was achieved in HO-8910PM-SI2 cells using matriptase-SI2. The mRNA and protein expression levels of matriptase and HAI-1 were comparable in HO-8910 and HO-8910-NC cells." compared with HO-8910PM-NC and HO-8910PM cells, significantly fewer HO-8910PM-SI2 cells survived and the number of early apoptotic HO-8910PM-SI2 cells was significantly higher. "P>0.05 vs. HO-8910PM; ${ }^{\text {P }<0.05 ~ v s . ~ H O-8910 P M . ~ Q 1, ~ c e l l u l a r ~ d e b r i s, ~ Q 2, ~}$ late apoptotic and necrotic cells, Q3, surviving cells, Q4, early apoptotic cells. NC, negative control; SI, small interfering RNA; HAI-1, hepatocyte growth factor activator inhibitor-1.

potential association between the invasiveness and metastatic ability, and the mRNA and protein expression levels of matriptase and HAI-1. As demonstrated in multiple previous reports, HO8910-PM cells are more invasive and metastatic compared with HO-8910 cells $(17,19,31,32)$. Tanimoto et al $(10)$ reported that the matriptase expression level is frequently elevated in early-stage ovarian cancer and declines as the disease progresses. However, Jin et al (13) demonstrated elevated matriptase immunostaining scores in serous adenocarcinoma were significantly correlated with the TNM and FIGO staging. 
An explanation for these differences may be that ovarian carcinoma subtypes exhibit different biological behaviors $(3,33)$. Notably, breast cancer also exhibits a similar diversity in matriptase expression and function $(34,35)$. Additionally, the variation may be associated with the expression of HAI-1. Oberst et al (15) reported that the ratio of matriptase/HAI-1 was increased in advanced-stage ovarian cancers. A similar increased ratio of matriptase/HAI-1 was also reported in advanced stage color cancer $(16,36)$. Upregulation of the ratio is dependent on increased expression of matriptase or decreased the expression of HAI-1. To maximize control of the other potential factors that may affect invasiveness and metastatic ability, the current study used a pair of homologous ovarian cell lines with similar genetic backgrounds. The results of the present study demonstrated that the increasing ratio of matriptase/HAI-1 ( 2 fold in HO-8910PM) was predominantly dependent on the relative increased expression of matriptase ( $\sim 3.6$ fold in mRNA and $\sim 2.3$ fold in protein), not the decreased expression of HAI-1, as the mRNA and protein levels of the latter were also increased by $\sim 1.7$ and 1.2 fold, respectively. Correlation analyses demonstrated that the different metastatic and invasive abilities of the ovarian cancer cells were positively correlated with the ratio of matriptase/HAI-1 and the expression level of matriptase, but not with the expression level of HAI-1. Furthermore, RT-qPCR and western blotting demonstrated that siRNA infection significantly decreased the matriptase expression level in HO-8910PM cells, resulting in significantly decreased in the HO-8910PM cell invasion and migration. Thus, it is concluded that the ovarian cancer cell metastasis and invasion was dependent on the activation of matriptase, but not on HAI-1.

The present study concluded that the ratio of matriptase/HAI-1 is directly and positively correlated with cellular invasion and metastasis, and the ratio is predominantly altered by changes in the expression level of matriptase. Thus, matriptase may be a potential therapeutic target. Results from flow cytometric analysis demonstrated that HO-8910PM-SI2 cells exhibited a greater proportion of $\mathrm{G}_{0} / \mathrm{G}_{1}$ phase cells and smaller proportion of $\mathrm{G}_{2} / \mathrm{M}$ phase cells compared with HO-8910PM and HO-8910PM-NC cells, indicating that matriptase downregulation results in ovarian cancer cell cycle arrest. Although the cellular apoptosis percentage in HO-8910PM-SI2 cells was significantly increased compared with HO-8910PM and HO-8910PM-NC cells, the apoptosis induced by siRNA is limited compared with cytotoxic drugs, such as cisplatin, which typically induce apoptosis in $\sim 30 \%$ of cells at $10 \mu \mathrm{M}$ (37). Other previous studies demonstrated that inhibition of matriptase enhances the treatment of hepatocellular carcinoma, breast cancer and prostate cancer $(38,39)$. In ovarian cancer, matriptase downregulation results in the inhibition of intraperitoneal tumor growth in nude mice and prolongs the mean survival of tumor-bearing mice (30). In the current study, as a candidate therapeutic target, matriptase suppression resulted in cell cycle arrest in the $G_{0} / G_{1}$ phase and induced limited apoptosis. Thus, targeting this protein may slow the progression of metastatic ovarian cancer, rather than providing a cure. Matriptase may be useful as target for adjuvant therapy for classical cytotoxic chemotherapy to limit cellular invasion and metastasis.

In summary, the findings of the current study suggest that the increased ratio of matriptase/HAI-1 is predominantly dependent on the increased expression level of matriptase, and it is a reliable indicator that reflects the aggressive nature of ovarian cancer cells. Matriptase may potentially be an adjuvant therapeutic target for inhibiting ovarian cancer invasion and metastasis.

\section{Acknowledgements}

This study was supported by Fujian Provincial Natural and Scientific Foundation (grant no. 2012J01310) and Key Program of Fujian Provincial Department of Science \& Technology (grant no. 2009Y0007).

\section{References}

1. Marczak A and Denel M: Trabectedin as a single agent and in combination with pegylated liposomal doxorubicin-activity against ovarian cancer cells. Contemp Oncol (Pozn) 18: 149-152, 2014.

2. Siegel R, Naishadham D and Jemal A: Cancer statistics, 2013. CA Cancer J Clin 63: 11-30, 2013.

3. Karst AM and Drapkin R: The new face of ovarian cancer modeling: Better prospects for detection and treatment. F1000 Med Rep 3: 22, 2011.

4. Liotta LA, Steeg PS and Stetler-Stevenson WG: Cancer metastasis and angiogenesis: An imbalance of positive and negative regulation. Cell 64: 327-336, 1991.

5. Chang $\mathrm{C}$ and Werb Z: The many faces of metalloproteases: Cell growth, invasion, angiogenesis and metastasis. Trends Cell Biol 11: S37-S43, 2001.

6. Tanimoto H, Underwood LJ, Wang Y, Shigemasa K, Parmley TH and O'Brien TJ: Ovarian tumor cells express a transmembrane serine protease: A potential candidate for early diagnosis and therapeutic intervention. Tumour Biol 22: 104-114, 2001.

7. Takeuchi T, Shuman MA and Craik CS: Reverse biochemistry: Use of macromolecular protease inhibitors to dissect complex biological processes and identify a membrane-type serine protease in epithelial cancer and normal tissue. Proc Natl Acad Sci USA 96: 11054-11061, 1999.

8. Szabo R and Bugge TH: Type II transmembrane serine proteases in development and disease. Int J Biochem Cell Biol 40: 1297-1316, 2008

9. Lin CY, Anders J, Johnson M, Sang QA and Dickson RB: Molecular cloning of cDNA for matriptase, a matrix-degrading serine protease with trypsin-like activity. J Biol Chem 274: 18231-18236, 1999.

10. Tanimoto H, Shigemasa K, Tian X, Gu L, Beard JB, Sawasaki T and O'Brien TJ: Transmembrane serine protease TADG-15 (ST14/Matriptase/MT-SP1): Expression and prognostic value in ovarian cancer. Br J Cancer 92: 278-283, 2005.

11. Nakamura K, Hongo A, Kodama J, Abarzua F, Nasu Y, Kumon H and Hiramatsu Y: Expression of matriptase and clinical outcome of human endometrial cancer. Anticancer Res 29: 1685-1690, 2009.

12. Szabo R, Rasmussen AL, Moyer AB, Kosa P, Schafer JM, Molinolo AA, Gutkind JS and Bugge TH: c-Met-induced epithelial carcinogenesis is initiated by the serine protease matriptase. Oncogene 30: 2003-2016, 2011.

13. Jin JS, Hsieh DS, Loh SH, Chen A, Yao CW and Yen CY: Increasing expression of serine protease matriptase in ovarian tumors: Tissue microarray analysis of immunostaining score with clinicopathological parameters. Mod Pathol 19: 447-452, 2006.

14. Benaud C, Dickson RB and Lin CY: Regulation of the activity of matriptase on epithelial cell surfaces by a blood-derived factor. Eur J Biochem 268: 1439-1447, 2001.

15. Oberst MD, Johnson MD, Dickson RB, Lin CY, Singh B, Stewart M, Williams A, al-Nafussi A, Smyth JF, Gabra H and Sellar GC: Expression of the serine protease matriptase and its inhibitor HAI-1 in epithelial ovarian cancer: Correlation with clinical outcome and tumor clinicopathological parameters. Clin Cancer Res 8: 1101-1107, 2002.

16. Vogel LK, Saebø M, Skjelbred CF, Abell K, Pedersen ED, Vogel U and Kure EH: The ratio of Matriptase/HAI-1 mRNA is higher in colorectal cancer adenomas and carcinomas than corresponding tissue from control individuals. BMC Cancer 6: 176, 2006. 
17. Jiang ZQ, Chen XF, Sun PM, Mao XD, Lin F and Song YY: Expression and significance of matriptase in ovarian cancer cells with diverse metastatic potential. Zhonghua Fu Chan Ke Za Zhi 48: 370-374, 2013 (In Chinese).

18. Mou HZ, Xu SH and Zhang YY: The establishment of human ovarian carcinoma cell line HO-8910 and its characteristics. Zhonghua Fu Chan Ke Za Zhi 29: 162-164, 191, 1994 (In Chinese).

19. Xu S, Mou H, Lü G, Zhu C, Yang Z, Gao Y, Lou H, Liu X, Cheng Y and Yang W: Gene expression profile differences in high and low metastatic human ovarian cancer cell lines by gene chip. Chin Med J (Engl) 115: 36-41, 2002.

20. Livak KJ and Schmittgen TD: Analysis of relative gene expression data using real-time quantitative PCR and the 2(-Delta Delta C(T)) method. Methods 25: 402-408, 2001.

21. Rosnoblet C, Legrand D, Demaegd D, Hacine-Gherbi H, de Bettignies G, Bammens R, Borrego C, Duvet S, Morsomme P, Matthijs $\mathrm{G}$ and Foulquier F: Impact of disease-causing mutations on TMEM165 subcellular localization, a recently identified protein involved in CDG-II. Hum Mol Genet 22: 2914-2928, 2013.

22. Liu Y, Han Y, Zhang H, Nie L, Jiang Z, Fa P, Gui Y and Cai Z: Synthetic miRNA-mowers targeting miR-183-96-182 cluster or miR-210 inhibit growth and migration and induce apoptosis in bladder cancer cells. PloS One 7: e52280, 2012.

23. Qi S, Song Y, Peng Y, Wang H, Long H, Yu X, Li Z, Fang L, Wu A, Luo W, et al: ZEB2 mediates multiple pathways regulating cell proliferation, migration, invasion and apoptosis in glioma. PloS One 7: e38842, 2012.

24. Yu LL, Chang K, Lu LS, Zhao D, Han J, Zheng YR, Yan YH, Yi P, Guo JX, Zhou YG, et al: Lentivirus-mediated RNA interference targeting the $\mathrm{H} 19$ gene inhibits cell proliferation and apoptosis in human choriocarcinoma cell line JAR. BMC Cell Biol 14: 26, 2013.

25. Hennessy BT, Coleman RL and Markman M: Ovarian cancer. Lancet 374: 1371-1382, 2009.

26. List K: Matriptase: A culprit in cancer? Future Oncol 5: 97-104, 2009.

27. Sanders AJ, Parr C, Davies G, Martin TA, Lane J, Mason MD and Jiang WG: Genetic reduction of matriptase-1 expression is associated with a reduction in the aggressive phenotype of prostate cancer cells in vitro and in vivo. J Exp Ther Oncol 6: 39-48, 2006.

28. Chou FP, Xu H, Lee MS, Chen YW, Richards OX, Swanson R, Olson ST, Johnson MD and Lin CY: Matriptase is inhibited by extravascular antithrombin in epithelial cells but not in most carcinoma cells. Am J Physiol Cell Physiol 301: C1093-C1103, 2011.
29. Lee SL, Dickson RB and Lin CY: Activation of hepatocyte grow th factor and urokinase/plasminogen activator by matriptase, an epithelial membrane serine protease. J Biol Chem 275: 36720-36725, 2000.

30. Suzuki M, Kobayashi H, Kanayama N, Saga Y, Suzuki M, Lin CY, Dickson RB and Terao T: Inhibition of tumor invasion by genomic down-regulation of matriptase through suppression of activation of receptor-bound pro-urokinase. J Biol Chem 279: 14899-14908, 2004.

31. Chen C, Sun MZ, Liu S, Yeh D, Yu L, Song Y, Gong L, Hao L, $\mathrm{Hu} \mathrm{J}$ and Shao S: Smad4 mediates malignant behaviors of human ovarian carcinoma cell through the effect on expressions of E-cadherin, plasminogen activator inhibitor-1 and VEGF. BMB Rep 43: 554-560, 2010.

32. Dong PX, Jia N, Xu ZJ, Liu YT, Li DJ and Feng YJ: Silencing of IQGAP1 by shRNA inhibits the invasion of ovarian carcinoma HO-8910PM cells in vitro. J Exp Clin Cancer Res 27: 77, 2008.

33. Köbel M, Kalloger SE, Boyd N, McKinney S, Mehl E, Palmer C, Leung S, Bowen NJ, Ionescu DN, Rajput A, et al: Ovarian carcinoma subtypes are different diseases: Implications for biomarker studies. PLoS Med 5: e232, 2008.

34. Parr C, Watkins G, Mansel RE and Jiang WG: The hepatocyte growth factor regulatory factors in human breast cancer. Clin Cancer Res 10: 202-211, 2004.

35. Kang JY, Dolled-Filhart M, Ocal IT, Singh B, Lin CY, Dickson RB, Rimm DL and Camp RL: Tissue microarray analysis of hepatocyte growth factor/Met pathway components reveals a role for Met, matriptase and hepatocyte growth factor activator inhibitor 1 in the progression of node-negative breast cancer. Cancer Res 63: 1101-1105, 2003.

36. Kosa P, Szabo R, Molinolo AA and Bugge TH: Suppression of tumorigenicity-14, encoding matriptase, is a critical suppressor of colitis and colitis-associated colon carcinogenesis. Oncogene 31: 3679-3695, 2012.

37. Sun PM, Wei LH, Luo MY, Liu G, Wang JL, Mustea A, Könsgen D, Lichtenegger W and Sehouli J: The telomerase activity and expression of hTERT gene can serve as indicators in the anti-cancer treatment of human ovarian cancer. Eur J Obstet Gynecol Reprod Biol 130: 249-257, 2007.

38. Welman A, Sproul D, Mullen P, Muir M, Kinnaird AR, Harrison DJ, Faratian D, Brunton VG and Frame MC: Diversity of matriptase expression level and function in breast cancer. PloS One 7: e34182, 2012.

39. Tripathi M, Potdar AA, Yamashita H, Weidow B, Cummings PT, Kirchhofer D and Quaranta V: Laminin-332 cleavage by matriptase alters motility parameters of prostate cancer cells. Prostate 71: 184-196, 2011. 